\title{
Voluntary Participation in Community Economic Development in Canada: An Empirical Analysis
}

\author{
Laura Lamb \\ Thompson Rivers University
}

\begin{abstract}
This article is an empirical analysis of an individual's decision to participate in community economic development (CED) initiatives in Canada. The objective of the analysis is to better understand how individuals make decisions to volunteer time toward CED initiatives and to determine whether the determinants of participation in CED are unique when compared to those of participation in volunteer activities in general. The dataset employed is Statistics Canada's 2004 Canada Survey of Giving, Volunteering and Participating (CSGVP). To date, there has been no prior econometric analysis of the decision to participate in community economic development initiatives in Canada. Results suggest a role for both public policymakers and practitioners in influencing participation in CED.
\end{abstract}

\section{RÉSUMÉ}

Cet article constitue une analyse empirique du processus de prise de décision chez les individus en ce qui a trait à la participation aux initiatives canadiennes de développement économique communautaire (DÉC). Le but de l'analyse est de mieux comprendre la façon dont les individus prennent la décision de consacrer du temps au bénévolat dans les initiatives de DÉC. Elle sert aussi à trancher la question de savoir si les facteurs de participation aux initiatives de développement économique communautaire sont uniques ou communs à la participation à des activités bénévoles en général. Les données employées dans le cadre de cette analyse sont puisées de l'Enquête canadienne sur le don, le bénévolat et la participation effectuée par Statistique Canada en 2004. À ce jour, aucune analyse économétrique n'a été menée sur la décision de participer aux initiatives canadiennes de DÉC. Les résultats suggèrent que les responsables de l'élaboration des politiques ainsi que les praticiens influencent tous deux la participation aux initiatives de DÉC.

\section{Keywords / Mots clés}

Community economic development; Volunteer; Rational choice theory; Collective action; Nonprofit sector / Développement économique communautaire; Théorie du choix rationnel; Bénévole; Action collective; Secteur sans but lucratif 


\section{Lamb (2011)}

\section{INTRODUCTION}

Voluntary participation in community economic development (CED) leads to positive benefits for the community and society at large through the provision of needed goods and services, such as social housing, worker training, and immigrant services. The current research endeavours to increase the understanding of how individuals make decisions to volunteer time for CED initiatives and to determine whether the determinants of participation in CED are unique when compared to volunteering in general. While the existing body of CED literature includes qualitative research on the determinants of participation in CED in Canada (Conn, 2006; Shragge, 2003), there appears to be a lack of quantitative research in this area, which the current research attempts to address.

This research is an analysis of an individual's decision to participate, or not, in a CED initiative using a traditional economic rational choice model. The rational choice model incorporates insights from the voluntary labour supply literature and socio-economic characteristics, and builds on the work of Torgler, Garcia-Valiñas, Macintyre and Ziemek (Torgler, Garcia-Valiñas, \& Macintyre, 2008; Ziemek, 2006). While the broader social sciences provide a body of literature on volunteer motives (such as Clary, Snyder, \& Stukas, 1996), this research focuses on an economics perspective of volunteer motives. Four questions are addressed. First, what are the determinants of an individual's decision to voluntarily participate in a CED initiative in Canada? Second, are the determinants of voluntarily participating in CED unique when compared to those of volunteering in general? Third, what are the determinants of the amount of time allocated toward voluntary participation in a CED initiative in Canada? And fourth, are the determinants of time allocated toward voluntary participation in CED different from those of volunteering in general?

For the purpose of this analysis participation in CED is defined as voluntary participation in development and housing organizations including organizations for community and neighbourhood, economic development, social development, housing associations, housing assistance, job training programs, vocation counselling and guidance, vocational rehabilitation, and sheltered workshops (International Classification of Nonprofit Organizations).

Community economic development (CED) has grown into a significant sector of Canada's social economy with close to 1,200 CED organizations currently engaged in various activities such as enterprise development, human capital development, and community capacity building, to name a few (Toye \& Chaland, 2006). The federal and provincial levels of government in Canada have come to recognize the importance of CED and provide varying levels of support. For instance, Western Economic Diversification, a federal government department developed to improve regional economic development, cites CED as one of its major activities (Western Economic Diversification, 2010). Many of the provincial governments also demonstrate support for CED and apply CED principles to their programs and policy. ${ }^{1}$

Given the growing recognition of the value of CED in Canadian society, this research is expected to be useful for both public policymakers and CED practitioners. From a public policy perspective, voluntary participation in CED organizations may be viewed as a benefit to society by creating output that would otherwise require paid resources. CED organizations play an essential role by producing needed goods and services not provided by the private sector due to various market failures. ${ }^{2}$ Generally speaking, voluntary participation in CED organizations leads to positive benefits for society, which public policymakers ought to encourage. CED practitioners may find the results useful for developing strategies to increase volunteer participation in CED. 


\section{Lamb (2011)}

This research contributes to the literature on CED, volunteering, and the non-profit sector. For instance, much of the volunteer literature is based on the assumption that the determinants of volunteer behaviour are homogeneous across the various charitable and non-profit sectors (Ziemek, 2006; Freeman, 1997; Van Dijk \& Boin, 1993). Those with higher household incomes are expected to have a higher probability of participating in volunteer activities than those with lower household incomes (Statistics Canada, 2006). As CED initiatives are often targeted toward low-income communities, household income levels may not be an important determinant of voluntary participation in CED. This research is designed to investigate these generalizations.

This article is organized as follows. First, are a description of CED and an outline of the role of participation in CED. Then the relevant economic theory is reviewed. Then the empirical model for testing is described. Followed by an explanation of the data, a discussion of econometric issues and techniques, and a description of the variables. Followed by an explanation of the empirical results. Then a discussion of policy implications and conclusions.

\section{LITERATURE}

\section{What Is Community Economic Development?}

Community economic development, also known in the literature as community-based development, is a "participatory, bottom-up approach to development" (Markey, Pierce, Vodden, \& Roseland, 2005, p. 2) with an emphasis on local self-sufficiency, local decision-making, and local ownership (Loxley, 1986). CED is viewed as a response to the failure of market-based approaches to development that had left numerous communities on the underdeveloped fringe of the economy over recent decades (Loxley, 2007; Shragge \& Toye, 2006). According to Shragge and Toye (2006), many of these communities which had been dependent on large-scale industrial and primary production suffered large numbers of job losses as a result of structural changes in the Canadian economy. Various federal and provincial government programs developed to support regional economic development failed to produce sustainable employment and growth, leaving many smaller and rural communities in a state of high unemployment and poverty (Shragge \& Toye, 2006). Since the advancement of CED across Canada in the 1980s, communities have surpassed governments in the development of community-based economic developments, eventually garnering government support for these CED program initiatives (Shragge \& Toye, 2006). CED in Canada has developed into a dynamic, enterprising, and growing group of organizations engaged in a wide variety of activities aimed at strengthening their communities (Toye \& Chaland, 2006).

\section{The Role of Participation in Community Economic Development}

Given that CED is a community-centred approach to development, the mobilization of community residents is essential for initiatives to be successful. The role of participation, often voluntary, is vital to ensure that initiatives respond to the needs and capacities of the community as expressed by the community itself (Fontan, Hamel, Morin, \& Shragge, 2006; Markey, Pierce, Vodden, \& Roseland, 2005; Mendell \& Evoy, 1993). The 2002 survey of CED organizations in Canada reveals that CED organizations play an important role in mobilizing citizen engagement and volunteer contributions in communities (Toye \& Chaland, 2006).

Attaining sufficient levels of participation is often challenging, particularly in marginalized communities frequently characterized as suffering from transience and a lack of community cohesiveness and commitment (Shragge, 2003). In many cases where a lack of social cohesion fails to generate a commitment to a common goal, community organizers, either from within or outside the community, play a role in 


\section{Lamb (2011)}

mobilizing people to act for their own interest in an organized way through community collective action (Shragge, 2003; Mendell \& Evoy, 1993). There are numerous cases where community organizers have drawn communities together for participation in collective action toward community initiatives (Fontan, Hamel, Morin, \& Shragge, 2006; Hanley \& Serge, 2006; MacIntyre \& Lotz, 2006; Shragge, 2003). Such collective action is typically targeted for participation in a specific development project, such as social housing or job training programs.

The aforementioned community organizers are frequently employed by community development organizations (CDOs). One role of CDOs is to initiate processes to bring community members together to support local development and to change defeatist attitudes, so pervasive after years of numerous development initiatives with varying levels of success (Fontan, Hamel, Morin, \& Shragge, 2006).

Qualitative community development research has uncovered some determinants of participation in CED initiatives in Canada. It has been observed that there is a positive relationship between an individual's willingness to participate and her or his expected benefits from participation (Shragge, 2003). The expected benefits may be for the betterment of the broader community, which might include social justice, provision of a municipal service, and building local institutions to provide economic opportunity. Personal individual benefits may include skills and leadership development, and the opportunity to meet and spend time with other people (Shragge, 2003; Hibbert, Piacentini, \& Al Dajani, 2003). Shragge (2003) observed a negative relationship between an individual's willingness to participate and the associated personal costs, which include time commitments-such as paid work and childcare-and energy levels. Observed obstacles to participation include a lack of confidence to being able to contribute to a project on the part of the potential participant, the defeatist attitude among community residents based on the belief that nothing will ever be accomplished, and lack of interest on the part of those who hope to move out of the community (Shragge, 2003; Hibbert, Piacentini, \& Al Dajani, 2003).

The CED literature suggests that several socio-economic factors are also likely to affect participation in CED initiatives. Gender has been identified as a significant socio-economic factor as women appear to dominate participation in the CED sector (Conn, 2006; Shragge, 2003). Shragge suggests that a high female participation rate may be grounded in the view that a neighbourhood is an extension of the home, and thus neighbourhood issues are more likely to attract women than men (Shragge, 2003). CED initiatives are typically developed for marginalized neighbourhoods and communities (e.g., characterized by economic poverty and associated social ills). Given this portrait, it is expected that those most likely to participate in CED would be in lower-income households, have lower levels of education, and be less likely to be employed (Shragge \& Toye, 2006; Loxley, 2007). Immigration status may also be a factor. The large number of CED organizations focusing on marginalized immigrant communities suggests that immigrant status may be associated with higher levels of participation (Toye \& Chaland, 2006). These qualitative observations are considered in the empirical model.

\section{THEORY}

\section{Contributions of Economic Theory}

A number of economic theories address the motivation and incidence of volunteering. These include rational choice theory, voluntary labour supply theory, human capital theory, and public goods theory.

According to rational choice theory, a rational individual will make the decision to participate in CED if the net 


\section{Lamb (2011)}

benefits are positive and will continue to volunteer time until the marginal net benefits equal zero. Some economic models define the benefits and costs of participating solely in terms of economic gain, while others adhere to a broader definition of gains using the concept of utility to describe the satisfaction one derives from her or his activities. For instance, a benefit may be the feeling of personal satisfaction from participating in a community project, whether it succeeds or not. Thus benefits often consist of private and public benefits while the costs are opportunity costs typically measured in terms of time. Opportunity costs, for example, include time that could have been spent caring for children, participating in leisure activities, or working for pay. The rational behavioural approach has been used extensively to address related research questions on participation in the community and civil society (Akinboye, Ayanwuyi, Kuponiyi, \& Oyetoro, 2007; Beard, 2007; Pattie, Seyd, \& Whiteley, 2003; Bryant \& White, 1982).

The economics of voluntary labour supply literature explores, identifies, and categorizes the motives behind volunteering (Ziemek, 2006; Freeman, 1997; Van Dijk \& Boin, 1993; Andreoni, 1990; Menchik \& Weisbord, 1987). Following Ziemek (2006), the private benefits of volunteering are classified as consumption and investment benefits and the public benefit is classified as the altruism benefit. This private consumption model is grounded in the notion that volunteers are motivated by the satisfaction derived from the "warm glow" feeling of doing something good, the achievement of a desired degree of social status, satisfaction at having carried out the work, or the fulfillment of social or ethical norms (Ziemek, 2006). The concept of a consumption benefit is supported by Cappellari and Turati's (2004) findings that individuals achieve a level of satisfaction from the act of volunteering itself. In addition, the consumption benefit is also influenced by negative incentives, as was found by Andreoni (1990), who reported that social pressure, guilt, sympathy, and avoidance of disapproval of others were additional determinants of volunteering.

The investment model is based on human capital theory and the assumption that volunteers are motivated to gain exchangeable benefits such as increasing job opportunities through the acquisition of skills, experience, and contacts (Ziemek, 2006; Van Dijk \& Boin, 1993). Volunteerism has been described as a latent requirement for certain occupations, providing a signal to potential employers that a volunteer is a "good" candidate (Ziemek, 2006). For the investment benefit to occur, volunteering itself does not need to provide satisfaction as volunteering is seen as a means to accrue a future benefit, such as higher future income (Cappellari \& Turati, 2004; Menchik \& Weisbord, 1987). The public goods model assumes that volunteers are motivated to increase the supply of the public good, and thereby obtain an altruistic benefit. In this case the volunteer is motivated by a sense of moral obligation prescribed by her or his own set of values. It is acknowledged that the common economic view of pure altruism is that it either does not exist at all or at best is very rare (Andreoni, 1990).

Rational choice theory and voluntary labour supply theory set the stage for the development of a model of voluntary participation in CED.

\section{EMPIRICAL MODEL}

\section{Modelling Participation in Community Economic Development}

Rational choice theory provides the structural framework for the proposed model of participation in CED while voluntary labour supply theory provides a method to articulate the private and public benefits of voluntary participation. The costs of participation are evaluated in terms of opportunity costs, as illustrated in Table 1. As stated above, participants may volunteer simply for the purpose of increasing the supply of a public or quasi-public good, subsequently receiving an altruistic benefit (A). The public goods resulting from CED 


\section{Lamb (2011)}

initiatives may include improved public health, improved physical environment, neighbourhood stability, improved relationships among communities and businesses, and community empowerment through local decision-making (Lamb, 2007). Private benefits are categorized as either consumption (C) or investment benefits (I). Consumption benefits associated with participating in CED initiatives may include the fulfillment of social norms, achievement of social status, satisfaction from the work involved in voluntary participation, or the warm feeling from having done a good deed. Investment benefits associated with participating in CED initiatives include improved opportunities for employment, job training, making new contacts, and in some cases better housing and improved health (Lamb, 2007; Pattie, Seyd, \& Whiteley, 2003). The costs of participation are the opportunity costs $(T)$ of devoting time to participate in a CED initiative, such as the time devoted to paid work and caring for children.

\section{Table 1: Model of participation in community economic development}

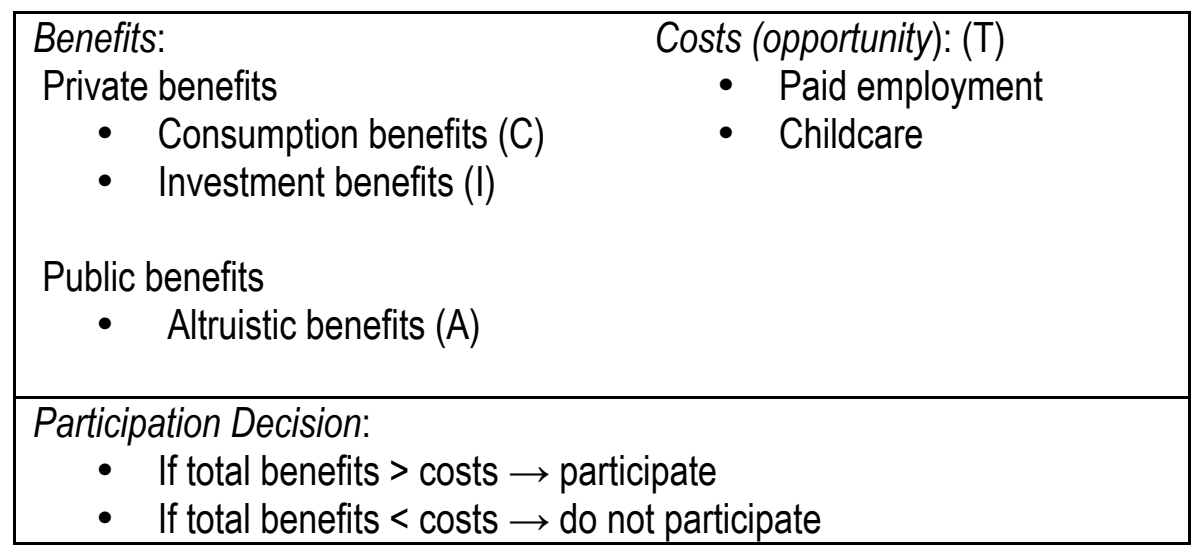

Voluntary labour supply theory predicts that individuals are motivated by either one or a combination of the three benefits (Menshik \& Weisbord, 1987). The economic theory of rational choice contends that the likelihood of participating increases with the number and strength of benefits and decreases with the quantity and strength of costs. The strength of each benefit and cost is measured by the size of the marginal effect on the decision to participate, as is described in the results subsection of the data analysis section. In addition, a set of socio-economic factors are included in the proposed models. Descriptive statistics on volunteering in Canada suggest participation may vary according to age, education, income, the presence of children, immigrant status, and religious activity (Statistics Canada, 2006). Statistics Canada (2006) reports that the likelihood of volunteering falls with age and immigration status, and increases with high household income, education, paid employment, the presence of children, and religious activity. In comparison, CED literature suggests the likelihood of volunteering for CED may decrease with high household income, education, and paid employment, and increase with immigrant status (Shragge \& Toye, 2006; Loxley, 2007). As previously mentioned, the CED literature suggests that gender is a determinant of participation in CED initiatives, with females being more likely to participate. The number of years spent living in the community is included as it may be a measure of social capital. It is expected that the likelihood of volunteering will increase at higher levels of social capital.

Four models are designed to address the following four questions: What are the determinants of an individual's decision to voluntarily participate in a CED initiative in Canada? Are the determinants of voluntarily participating in CED unique when compared to those of volunteering in general? What are the determinants of the amount of time allocated toward voluntary participation in a CED initiative in Canada? 


\section{Lamb (2011)}

Are the determinants of time allocated toward voluntary participation in CED different from those of volunteering in general?

Model 1: Determinants of an individual's decision to voluntarily participate in a CED initiative are summarized by the following function:

$$
P_{\text {ced }}=F(A, C, I, T, S)
$$

where $P_{\text {ced }}$ represents an individual's decision to voluntarily participate in a community economic development initiative, A represents altruism benefits, $C$ represents consumption benefits, I represents investment benefits, $T$ represents the time costs of participation, and $\mathrm{S}$ represents the set of socio-economic factors.

Model 2: An individual's decision to volunteer in general is summarized by the following function:

$$
P=F(A, C, I, T, S)
$$

where $\mathrm{P}$ represents an individual's decision to volunteer for any type of organization.

Model 3: An individual's decision about how many hours to volunteer for CED organizations is summarized by the following function:

$$
H_{\text {ced }}=F(A, C, I, T, S)
$$

where the dependent variable is the number of hours $\left(\mathrm{H}_{\mathrm{ced}}\right)$ devoted to volunteering for CED.

Model 4: An individual's decision about how many hours to volunteer for any organization is summarized by the following function:

$$
H=F(A, C, I, T, S)
$$

where the dependent variable is the number of hours $(H)$.

The following hypotheses are tested:

Hypothesis 1: In accordance with economic theory, an individual's decision to voluntarily participate in a CED initiative is positively affected by private and public benefits and negatively affected by the costs of participating, as measured by opportunity costs.

Hypothesis 2: In accordance with economic theory, the amount of additional time an individual is likely to devote to a CED initiative is positively affected by private and public benefits and negatively affected by the costs of participating, as measured by opportunity costs.

Hypothesis 3: Females are more likely to participate in a CED initiative than males, as suggested by the CED literature.

Hypothesis 4: The set of determinants of voluntary participation in CED are different from the determinants of volunteering in general.

Hypothesis 5: The set of determinants of additional time devoted to voluntary participation in CED are different from the determinants of additional time devoted to volunteering in general. 


\section{Lamb (2011)}

\section{DATA ANALYSIS}

\section{Empirical Analysis of Participation in Community Economic Development}

Empirical analysis of the four models yields the results needed to test the five hypotheses. This section includes an explanation of the data, a discussion of econometric issues and techniques, and descriptions of the variables.

\section{Data}

The data is from the 2004 Canada Survey of Giving, Volunteering and Participating (CSGVP), published by Statistics Canada. It was selected over the more recent 2007 CSGVP because it contains a superior set of variables for this analysis. The objective of the survey is to collect data on unpaid volunteer activities, charitable giving, and participation. The target population for the 10 provinces is all persons 15 years of age or over, excluding full-time residents of institutions. Approximately 20,832 respondents were interviewed between September and December 2004 in the 10 provinces. After the variables for the four models were identified, observations with missing data were excluded from the analysis, leaving a sample of 18,297 observations.

\section{Econometric issues}

Two econometric issues affect the interpretation of the empirical results. First, the estimation for all four models may involve the econometric issue of endogeneity. Each model comprises a dependent variable and several independent variables. The endogeneity problem could affect the use of two independent variables, hours worked and charitable donations. The number of hours worked might be affected by the decision to participate in CED or in general volunteering. For instance, an individual may decide to work fewer hours because of her or his involvement in volunteer activities. As well, the number of hours worked may be affected by the number of hours devoted to CED in addition to general volunteering. In other words, the number of hours worked and the decision to volunteer may be determined simultaneously. The instrument variable technique is a statistical methodology used to overcome the endogeneity problem by adding instrument variables to the empirical estimation process. Instrument variables are chosen to be correlated with the endogenous variable but not to the dependent variable. Employment status is added to the estimation as an instrument variable for hours worked in all four models. Likewise, the decision to make a charitable donation may be affected by participation in CED and/or by volunteering in general in Models 1 and 2. For example, an individual may become more aware of the importance and need for charitable donations when participating in volunteer activities. Contributing to a church collection and making a donation to a health organization are both used as instrument variables for the decision to make a charitable donation.

Second, selectivity bias arises in the analysis of Model 1 because the decision to participate by non-participants in CED organizations is not observed. For example, preferences for volunteering in CED are on average expected to be higher in a sample of those who volunteer their time in at least one CED organization. Likewise, the econometric issue of selectivity bias arises in the analysis of Models 3 and 4 because the number of hours volunteered by non-participants in both CED organizations and volunteer organizations in general are not observed, and because the participants are self-selected, they do not comprise a random sample. ${ }^{4}$ For example, preferences for volunteering more hours to CED organizations are on average presumably higher in a sample of those who volunteer their time in at least one CED organization. Heckman's sample selection model is used to mitigate selectivity bias in Models 1, 3, and 4. The maximum likelihood approach, ${ }^{5}$ in which 


\section{Lamb (2011)}

observations are weighted to correct for different sampling probabilities, is used.

\section{Variables}

\section{Dependent variables}

Model 1: Participation in CED is constructed as a dichotomous variable with a value of unity if the survey respondent indicates participation in at least one CED organization, and zero otherwise. A total of 1,301 survey respondents have participated in community economic development initiatives as defined by voluntary participation in at least one organization for development and housing, based on the International Classification of Nonprofit Organizations (ICNPO).

Model 2: Participation in volunteering in general is constructed as a dichotomous variable with a value of unity if the sample member indicates participation in at least one volunteer organization, based on the International Classification of Nonprofit Organizations (ICNPO). ${ }^{6}$ A total of 11,791 survey respondents have participated in volunteer activities.

Model 3: The number of additional hours devoted to voluntary participation in CED is constructed as a continuous variable with a value ranging from 1 to 2,016 hours if the sample member indicates participation in at least one volunteer organization for development and housing. The natural log of the number of hours is used in the model.

Model 4: The number of additional hours devoted to volunteering in general is constructed as a continuous variable with a value ranging from 1 to 8,750 hours if the sample member indicates participation in at least one volunteer organization. The natural log of the number of hours is used in the model.

\section{Independent variables}

The independent variables consist of proxy variables for the private benefits of investment and consumption, the public benefit of altruism, the time costs of volunteering, and socio-economic variables.

\section{Investment benefit}

The investment benefit is measured with three proxy variables; the first is student status ( $1=y e s ; 0=n o)$, as students are likely to volunteer to receive an investment benefit given that most are in the life-cycle stage where they are seeking to develop human capital with work experience and skill development, as well as developing networks to maximize employment and promotion opportunities. The second proxy is selfemployment status ( $1=y e s ; 0=n o$ ). The rational is based on the belief that many self-employed individuals are involved in businesses reliant on forming networks, so volunteering is a means to meet people and create networks. The third proxy variable represents a company policy to encourage volunteer participation by employees $(1=y e s ; 0=n o)$. Those whose employers encourage volunteering may choose to participate in volunteer activities to improve the likelihood of promotion and higher earnings in the future. The third proxy is not included in Model 2 (general volunteering) because the question is only asked to those who have volunteered.

\section{Consumption and altruistic benefits}

A pure consumption benefit is measured with a dichotomous variable for the response to the question of whether the individual was asked to volunteer $(1=y e s ; 0=n 0)$. Previous research has shown that individuals are more likely to volunteer when asked (Freeman, 1997). The tendency of individuals to volunteer when 


\section{Lamb (2011)}

asked can be explained with the concept of a "conscience good" which describes a good or service one provides out of a feeling of social pressure (Freeman, 1997). This variable is not included in Model 2 (general volunteering) because the question is only asked to those who have volunteered.

Two proxy variables represent both consumption and altruistic benefits. The proxy variable of retirement is measured with sample members in the age range of 55 and older. Ziemek (2006) used retirement as a variable to measure both consumption and altruistic benefits. Retired or almost-retired individuals are likely to volunteer for personal consumption or altruistic benefits because they are past the life-cycle stage where they are concerned with investment benefits such as promotion opportunities. The proxy variable of informal volunteering ( $1=y e s ; 0=$ no) is expected to be motivated by consumption and/or altruism benefits, because it lacks the formal recognition gained when volunteering for an organization, such as a development agency.

\section{Time cost variables}

The opportunity costs are measured in terms of time constraints due to family and employment. The proxy variables are the presence of children in the household ( $1=y e s ; 0=$ no) and the numbers of hours worked per week in paid employment ( $1=40$ or more hours per week; $0=$ less than 40 hours per week). Van Dijk and Boin (1993) used both these variables as measures of time costs of volunteering.

\section{Socio-economic variables}

The socio-economic variables are listed and described in Table 2.

Table 2: Socio-economic variables

\begin{tabular}{|c|c|c|}
\hline \multicolumn{2}{|l|}{ Variable Name } & Description \\
\hline Gender & Male & Gender of the respondent (Male $=1 ;$ female $=0$ ). \\
\hline Education & Postsecondary education & $\begin{array}{l}\text { Respondents whose educational attainment includes at } \\
\text { least some postsecondary education ( } 1=y e s ; 0=n o) \text {. }\end{array}$ \\
\hline Age (2 variables) & $\begin{array}{l}35-54 \text { years } \\
55+\text { years }\end{array}$ & $\begin{array}{l}\text { Respondents in the age range } 35 \text { to } 54 \text { ( } 1=y e s ; 0=\text { no). } \\
\text { Respondents in the age range } 55 \text { and over ( } 1=y e s ; 0=\text { no). }\end{array}$ \\
\hline $\begin{array}{l}\text { Household income } \\
\text { (2 variables) }\end{array}$ & $\begin{array}{l}\$ 40,000-100,000 \\
\$ 100,000+\end{array}$ & $\begin{array}{l}\text { Respondents for whom annual household income was in } \\
\text { the range } \$ 40,000 \text { to } \$ 100,000 \text { ( } 1=\text { yes; } 0=\text { no). } \\
\text { Respondents for whom annual household income was } \\
\text { greater than } \$ 100,000 \text { ( } 1=\text { yes; } 0=\text { no). }\end{array}$ \\
\hline Religiosity & Religious attendance & $\begin{array}{l}\text { Respondents who attended a religious service or meeting } \\
\text { at least weekly }(1=y e s ; 0=\text { no). }\end{array}$ \\
\hline Immigration status & Canadian-born & Respondents who were born in Canada ( $1=y e s ; 0=$ no). \\
\hline Attachment to community & Time in community & $\begin{array}{l}\text { Respondents who have lived in the community for at least } \\
\text { five years }(1=y e s ; 0=\text { no). }\end{array}$ \\
\hline $\begin{array}{l}\text { Participation in } \\
\text { charitable giving }\end{array}$ & Charitable donations & $\begin{array}{l}\text { Respondents who have participated in charitable giving to } \\
\text { at least one organization in the past year }(1=y e s ; 0=\text { no). }\end{array}$ \\
\hline
\end{tabular}

\section{RESULTS}

This section presents the results of empirical testing of the four models. Frequency and percentage distribution statistics of voluntary participation in community economic development according to socio-economic characteristics are presented in Table 3 . The results show that $54 \%$ of CED participants are female, $74 \%$ have 
at least some postsecondary education, $47 \%$ are between the ages of 35 and $54,40 \%$ have a household income in the range of $\$ 40,000-\$ 100,000,22 \%$ attend religious meetings at least weekly, $80 \%$ have lived in their community for at least five years, 87\% were born in Canada, and 95\% made a charitable donation in 2004.

\section{Table 3: Frequency and percentage distribution of voluntary participation in community economic development according to their socio-economic characteristics $(n=1302)$}

\begin{tabular}{|c|c|c|}
\hline $\begin{array}{l}\text { Socio-economic } \\
\text { characteristics }\end{array}$ & Frequency & $(\%)$ \\
\hline $\begin{array}{l}\text { Age } \\
15-34\end{array}$ & 316 & 24.2 \\
\hline $35-54$ & 614 & 47.2 \\
\hline $55+$ & 372 & 28.6 \\
\hline Total & & 100.0 \\
\hline $\begin{array}{l}\text { Gender } \\
\text { Female }\end{array}$ & 703 & 54.0 \\
\hline Male & 599 & 46.0 \\
\hline Total & & 100.0 \\
\hline $\begin{array}{l}\text { Education maximum } \\
\text { High school diploma }\end{array}$ & 338 & 26.0 \\
\hline At least some postsecondary & 964 & 74.0 \\
\hline Total & & 100.0 \\
\hline $\begin{array}{l}\text { Household income } \\
<\$ 40,000\end{array}$ & 131 & 10.1 \\
\hline$\$ 40,000-\$ 100,000$ & 903 & 40.7 \\
\hline$\$ 100,000+$ & 268 & 20.6 \\
\hline Total & & 100.0 \\
\hline $\begin{array}{l}\text { Religious attendance } \\
\text { At least weekly }\end{array}$ & 287 & 22.0 \\
\hline Less than weekly/never & 1015 & 78.0 \\
\hline Total & & 100.0 \\
\hline $\begin{array}{l}\text { Time in community } \\
\text { Less than } 5 \text { years }\end{array}$ & 263 & 20.0 \\
\hline$\geq 5$ years & 1039 & 80.0 \\
\hline Total & & 100.0 \\
\hline Immigrant status & & \\
\hline Canadian born & 1130 & 87.0 \\
\hline Immigrant & 172 & 13.0 \\
\hline Total & & 100.0 \\
\hline $\begin{array}{l}\text { Charitable donations } \\
\text { Participant }\end{array}$ & 1238 & 95.0 \\
\hline Non-participant & 64 & 5.0 \\
\hline Total & & 100.0 \\
\hline
\end{tabular}

The marginal effects of the explanatory variables on the decision to participate in Models 1 and 2 are presented in Table 4. The marginal effects of the explanatory variables on additional time devoted to voluntary participation in Models 3 and 4 are displayed in Table 5. 


\section{Lamb (2011)}

Table 4: Marginal effects for participation in community development and general volunteering

\begin{tabular}{|c|c|c|}
\hline & $\begin{array}{l}\text { CED } \\
\text { (Model 1) }\end{array}$ & $\begin{array}{l}\text { Volunteering } \\
\text { (Model 2) }\end{array}$ \\
\hline Children & $\begin{array}{l}.008^{*} \\
(.004)\end{array}$ & $\begin{array}{l}.287^{* *} \\
(.042)\end{array}$ \\
\hline Hours worked & $\begin{array}{l}.010^{\star *} \\
(.003)\end{array}$ & $\begin{array}{l}-.195^{\star *} \\
(.042)\end{array}$ \\
\hline Male & $\begin{array}{l}.004 \\
(.003)\end{array}$ & $\begin{array}{l}-.150^{* *} \\
(.038)\end{array}$ \\
\hline Postsecondary education & $\begin{array}{l}-.003 \\
(.005)\end{array}$ & $\begin{array}{l}-.223^{\star *} \\
(.049)\end{array}$ \\
\hline Age: $35-54$ & $\begin{array}{l}.012^{* *} \\
(.004)\end{array}$ & $\begin{array}{l}.0003^{* *} \\
(.047)\end{array}$ \\
\hline $55+$ (retired) & $\begin{array}{l}.020^{* *} \\
(.007)\end{array}$ & $\begin{array}{l}.027^{*} \\
(.059)\end{array}$ \\
\hline Household income: $\$ 40,000-100,000$ & $\begin{array}{l}.006 \\
(.005)\end{array}$ & $\begin{array}{l}.082^{*} \\
(.041)\end{array}$ \\
\hline$\$ 100,000+$ & $\begin{array}{l}.006 \\
(.004)\end{array}$ & $\begin{array}{l}.174^{* *} \\
(.057)\end{array}$ \\
\hline Consumption benefit: Asked & $\begin{array}{l}.043^{* *} \\
(.005)\end{array}$ & - \\
\hline Altruistic benefit: Informal volunteer & $\begin{array}{l}.022^{* *} \\
(.004)\end{array}$ & $\begin{array}{l}.433^{* *} \\
(.053)\end{array}$ \\
\hline Investment benefits: Student & $\begin{array}{l}.016^{* *} \\
(.006)\end{array}$ & $\begin{array}{l}.673^{* *} \\
(.059)\end{array}$ \\
\hline Employer policy & $\begin{array}{l}.046^{\star *} \\
(.009)\end{array}$ & - \\
\hline Self-employed & $\begin{array}{l}.054^{* *} \\
(.009)\end{array}$ & - \\
\hline Time in community & $\begin{array}{l}-.002 \\
(.008)\end{array}$ & $\begin{array}{l}.073 \\
(.041)\end{array}$ \\
\hline Canadian-born & $\begin{array}{l}.005 \\
(.004)\end{array}$ & $\begin{array}{l}.166^{* *} \\
(.049)\end{array}$ \\
\hline Religious attendance & $\begin{array}{l}-.004 \\
(.004)\end{array}$ & $\begin{array}{l}.462^{* *} \\
(.047)\end{array}$ \\
\hline Charitable donations & $\begin{array}{l}.016^{* *} \\
(.005)\end{array}$ & $\begin{array}{l}.060^{* *} \\
(.094)\end{array}$ \\
\hline Wald Statistic & 514.69 & 604.07 \\
\hline
\end{tabular}

Note: Robust standard errors are reported in parentheses.

* indicates significance at the level $p<0.05$.

** indicates significance at the level $p<0.01$.

Probit is used for the CED regression and ivprobit for the volunteering regression. 


\section{Lamb (2011)}

Table 5: Marginal effects for hours spent on participation in community development and general volunteering

\begin{tabular}{|c|c|c|}
\hline & $\begin{array}{c}C E D \\
\text { (Model 3) }\end{array}$ & $\begin{array}{l}\text { Volunteering } \\
\text { (Model 3) }\end{array}$ \\
\hline Children & $\begin{array}{l}-.145 \\
(.123)\end{array}$ & $\begin{array}{l}-.099^{*} \\
(.049)\end{array}$ \\
\hline Hours worked & $\begin{array}{l}-.75^{* *} \\
(.299)\end{array}$ & $\begin{array}{l}-.520^{* *} \\
(.132)\end{array}$ \\
\hline Male & $\begin{array}{c}.076 \\
(.122)\end{array}$ & $\begin{array}{l}.154^{* \star} \\
(.050)\end{array}$ \\
\hline Postsecondary education & $\begin{array}{l}-.512^{* *} \\
(.155)\end{array}$ & $\begin{array}{l}-.349^{* *} \\
(.070)\end{array}$ \\
\hline Age: $35-54$ & $\begin{array}{c}.212 \\
(.141)\end{array}$ & $\begin{array}{l}.206^{* *} \\
(.054)\end{array}$ \\
\hline $55+$ & $\begin{array}{l}.355 \\
(.203)\end{array}$ & $\begin{array}{l}.323^{* *} \\
(.081)\end{array}$ \\
\hline $\begin{array}{l}\text { Household income: } \$ 40,000- \\
\qquad 100,000\end{array}$ & $\begin{array}{c}-.001 \\
(.129) \\
.287\end{array}$ & $\begin{array}{l}.086 \\
(.051) \\
.224^{* *}\end{array}$ \\
\hline$\$ 100,000+$ & $\begin{array}{l}(.163) \\
.278^{*}\end{array}$ & $\begin{array}{l}(.065) \\
-.426^{* *}\end{array}$ \\
\hline Consumption benefit: Asked & $\begin{array}{c}(.102) \\
.323\end{array}$ & $\begin{array}{l}(.040) \\
.367^{* *}\end{array}$ \\
\hline $\begin{array}{l}\text { Altruistic benefit: Informal } \\
\text { volunteer }\end{array}$ & $\begin{array}{l}(.249) \\
-.337 \\
(.179)\end{array}$ & $\begin{array}{l}(.075) \\
-.026 \\
(.073)\end{array}$ \\
\hline Investment benefits: Student & $\begin{array}{l}.16 \\
(.137)\end{array}$ & $\begin{array}{l}-.014 \\
(.061)\end{array}$ \\
\hline Employer policy & $\begin{array}{l}.114 \\
(.140)\end{array}$ & $\begin{array}{l}.256^{* *} \\
(.056)\end{array}$ \\
\hline Self-employed & $\begin{array}{l}.136 \\
(.127)\end{array}$ & $\begin{array}{l}.124^{* *} \\
(.051)\end{array}$ \\
\hline Time in community & $\begin{array}{l}-.344^{* *} \\
(.139)\end{array}$ & $\begin{array}{l}.095 \\
.058)\end{array}$ \\
\hline Canadian-born & $\begin{array}{l}.195 \\
(.125)\end{array}$ & $\begin{array}{l}.591^{* *} \\
(.046)\end{array}$ \\
\hline Religious attendance & $\begin{array}{l}-.370 \\
(.240)\end{array}$ & $\begin{array}{l}.102 \\
(.081)\end{array}$ \\
\hline Charitable donations & & \\
\hline Wald Statistic & $67.12^{* *}$ & $573.87^{* *}$ \\
\hline
\end{tabular}

Note: Robust standard errors are reported in parentheses.

*indicates significance at the level $p<0.05$.

** indicates significance at the level $p<0.01$. 


\section{Lamb (2011)}

\section{PARTICIPATION MODELS}

Overall, the specifications of Models 1 and 2 are robust. ${ }^{7}$ The results of Model 1 support the predictions of economic theory as they imply that both private and public benefits increase the likelihood of volunteering for CED organizations. The investment benefit of volunteering for CED is an important determinant as evidenced by the significance of student status, self-employment status, and working for an employer with a policy to promote volunteer activities. Self-employment status has the largest marginal effect, suggesting that selfemployed individuals have a $5.4 \%$ higher likelihood of volunteering for a CED organization than those who are not self-employed. The consumption benefit is also a determinant as evidenced by the asked variable. Support for the public benefit is suggested with the significance of participation in informal volunteer activities and a higher probability of participation by those over the age of 55 .

The results for the time costs of participating in CED organizations are mixed. As predicted by economic theory, hours worked has a negative and significant coefficient, implying that those who work more than 40 hours per week have a lower probability of volunteering for CED than those who work fewer than 40 hours per week. However, contrary to economic theory, the presence of children in the household is positive and significant, suggesting that having children increases the likelihood of volunteering for CED. This unexpected result may be explained by a parent's concern for the future state of society and thus a greater willingness to participate in CED in order to better the world for her or his children (Dupont, 2004). With the exception of the presence of children variable, the results provide support for Hypothesis 1.

The socio-economic variables age and charitable donations are both positive and significant. The likelihood of volunteering for CED organizations increases with age and is highest for those over the age of 55 . Those who make charitable donations are more likely to volunteer for CED than those who do not, implying that donating and volunteering are complements rather than substitutes. Gender is not a determinant of voluntarily participating in a CED initiative and thus there is no support for Hypothesis 3.

Empirical results for Model 2, the general volunteering model, reveal that the significance of the benefits and time cost variables are reasonably consistent across both models. The uniqueness of volunteering for CED organizations is revealed by the difference across the socio-economic factors, offering support for Hypothesis 4. While the likelihood of volunteering in Canada appears to increase with household income, education, and religious involvement, and to decrease with immigrant status, none of these factors are significant determinants of volunteering for a CED initiative.

\section{TIME DEVOTED TO PARTICIPATION}

Overall, the specifications of Models 3 and 4 are robust. ${ }^{8}$ Model 3 results suggest limited support for Hypothesis 2 given that only the private consumption benefit, indicated by being asked to volunteer, increases the likelihood of devoting more time to CED organizations. Both measures of time costs of volunteer participation are negative, as expected, but only hours worked is significant. In support of economic theory, those who work fewer than 40 hours per week are $75 \%$ more likely to spend additional time volunteering for CED than those who work more than 40 hours per week. The socio-economic variables of education and country of birth are statistically significant. The results imply that those with less than postsecondary education have a $51 \%$ higher probability of devoting more time to volunteering for CED. Immigrants have a $34 \%$ higher probability of spending additional time on CED than those who are Canadian-born. Economic theory is not as effective at explaining the time devoted to CED as it is at explaining a decision to participate. 


\section{Lamb (2011)}

Empirical results for Model 4, general volunteering, indicate that the set of determinants of the time devoted to volunteering for CED differs from those for volunteering in general. For general volunteering, both private and public benefits are significant determinants of the additional time devoted to general volunteering, contrary to volunteering for CED where only the private consumption benefit is significant. The socioeconomic variables of gender, age, income, time in the community, and religious attendance are uniquely significant determinants for the amount of additional time spent on volunteering in general, but not on volunteering for a CED initiative, thus providing support for Hypothesis 5.

\section{SUMMARY}

The empirical results indicate that the determinants of the decision to volunteer and to devote additional time to CED organizations are different from those of volunteering in general. As predicted, household income is not a significant determinant of CED initiatives as it is for general volunteering. The gender results for participation and time devoted to CED are unexpected given that the CED literature emphasizes the important role of women (Conn, 2006; Shragge, 2003). Perhaps gender is influenced by the unavailability of affordable daycare or even the nature of community economic activities. Further research on gender is required to sort out the relationship between gender and participation and time devoted to CED activities. Although education is not a determinant of participation in CED, it is significant and negative for the time devoted to CED activities. Individuals with less than postsecondary education have a higher probability of devoting additional hours to CED activities.

In sum, the results provide support for economic theory evidenced by the increased likelihood of participation in CED activities associated with private consumption and investment benefits and possibly altruism benefits, and the decreased likelihood associated with the number of hours spent working for pay. The likelihood of participating is positively affected by the presence of children in the household, an increase in age, and participation in charitable giving. The unpredicted positive influence of children on participation may indicate an investment or consumption benefit rather than an opportunity cost. Parents may participate as an investment in future community betterment for their children or they may participate in community and neighbourhood projects related to their children's activities to fulfill social norms.

The probability of devoting additional time toward CED activities is positively affected by consumption benefits and negatively affected by the number of hours spent working for pay, providing some support for economic theory. The CED literature provides support for the significance of the probability of devoting additional time being positively affected by immigrant status and negatively affected by postsecondary education. The level of involvement of immigrants is not surprising given the numerous immigrant-focused CED organizations. Those with less than a postsecondary education likely have the most to gain from devoting additional hours to CED projects, particularly in the areas of job training programs and vocational counselling and guidance.

Unlike general volunteering, the probability of volunteer participation in CED does not appear to be influenced, either positively or negatively, by gender, postsecondary education, household income, immigration status, or degree of religious involvement, as none of these variables are significant. Likewise, the likelihood of spending additional time on CED activities does not appear to be affected by gender, age, length of time spent living in the community, or degree of religious involvement, as indicated by the lack of statistical significance of those variables. 


\section{Lamb (2011)}

\section{POLICY IMPLICATIONS AND CONCLUSIONS}

\section{Public policy}

The determinants of voluntary participation in CED provide useful information for public policymakers for developing effective programs to support the CED sector. For instance, the public sector might develop programs for the purpose of increasing private and public benefits in order to stimulate a higher level of participation in CED activities. Public policy can address consumption and altruistic benefits by providing public information through media about the value of participation in the CED sector, such as building a community understanding and appreciation of CED volunteers and the contributions they make to the community, economy, and society. For example, an individual motivated by consumption benefits may become aware of the fulfillment of social norms and the potential achievement of social status associated with participation, whereas an individual motivated by altruistic benefits will become informed about the important contributions to the community and may subsequently be motivated to participate by a sense of moral obligation. Similarly, public policy can address investment benefits by providing public information through media about the opportunities for skills development, work experience, and networking from participation in CED.

Public policy directed at improving the success rate of CED initiatives is expected to have a positive effect on the consumption benefit, and perhaps the altruistic benefit, and subsequently on voluntary participation in CED. For example, in order for an individual to experience the "warm glow" effect associated with doing something good, she or he must believe that their involvement in the proposed volunteer project will make a positive contribution to society (or the community). For instance, if potential volunteers do not believe that a community initiative will get off the ground or be successful, then there is no potential for the "warm glow" effect. In a similar manner, an altruistic benefit is associated with the provision of a needed good or service, such as job training or housing. If a CED project is not expected to result in the provision of something for the public good, then the altruistic benefit will not be realized. The issue of expected success of a project is particularly relevant to CED as explained earlier, where CED practitioners often face challenges in motivating and bringing together community residents and dealing with defeatist attitudes stemming from years of unsuccessful attempts at development (Fontan, Hamel, Morin, \& Shragge, 2006; Shragge, 2003).

Proposed programs to support CED may include, for example, the provision of funding, financing, tax credits for private investment in CED, and procurement policy. While there are many different types of tax incentives, a tax credit program is regarded as the most effective type of tax incentive program (Perry, 2009). For example, the public sector could assist in the provision of funding by implementing a comprehensive tax credit program for CED projects similar to the Community Development Financial Authority (CDFA) in New Hampshire in the United States (Perry, 2009). Some provinces, such as Nova Scotia and Manitoba, have provided tax credits for CED projects, but only to individuals. The New Hampshire program also provides tax credits to corporations and banks. In addition, the CDFA provides programs to address competence and capacity in the CED sector.

The results provide support for the notion of providing a tax incentive for volunteer participation, similar to the tax credit for charitable giving. Hours devoted to paid work have a negative impact on the probability of volunteering for $\mathrm{CED}$ and on the probability of devoting more hours to volunteering, implying that some form of compensation would reduce the costs of volunteering, thereby increasing the likelihood of participating in volunteer activities. It is noted that existing literature on the topic of proposed tax incentives for volunteering 


\section{Lamb (2011)}

does not reach a consensus about the expected effectiveness of such an incentive (Frey \& Goette, 1999; Spyker \& Peloza, 2009).

\section{CED policy and practice}

Many of the public policy strategies discussed above are pertinent to the CED community, particularly intermediary organizations such as CCED-NET. ${ }^{9}$ In addition, the research results suggest implications for CED policy and practice. Strategies to increase the number of volunteers and the amount of time devoted to volunteer activities might involve enhancing the private and public benefits. For example, activities to increase consumption benefits might include providing recognition for contributions to the project and to the community through articles and commendations. Forming a connection between a specific volunteer task and its contribution to the CED project and to the community is important in providing a sense of satisfaction associated with the consumption benefit.

CED organizations may enhance investment benefits by increasing opportunities to develop skills, gain work experience, and build networks. Given the significance of the investment benefit in the empirical results, one strategy is to target youth. For instance, some university and college programs-marketing and human resources, for example-include courses that require student-applied projects for non-profit organizations.

CED organizations can take steps to increase participation and the number of hours of volunteering by assigning volunteers to tasks according to their particular motivations and characteristics. Volunteer data could be collected through a survey questionnaire on demographic characteristics, motivations, and personal interests. Past research shows that matching volunteers to activities that correspond with their motivations will increase levels of participation and increase retention rates of volunteers (Peterson, 2004; Hibbert, Piacentini, \& Al Dajani, 2003; Clary, Snyder, \& Ridge, 1992). For example, younger volunteers are more likely to volunteer for investment benefits while more mature volunteers are more likely to volunteer for consumption benefits associated with making new social connections and spending time with people (Peterson, 2004). Research on participation in a community-based food cooperative by Hibbert, Piacentini, and Al Dajani (2003) reports the importance of volunteer participants having a matching interest in the particular characteristic of a given CED project. For example, one volunteer for the food retail cooperative emphasized that she loved to cook while another expressed strong views about the need for access to lowpriced food for low-income families.

Based on the heterogeneity of CED organizations, it is reasonable to assume that some projects and organizations are likely to provide greater opportunities for investment benefits while others are likely to offer greater opportunities for consumption or altruistic benefits. The creation of a central CED volunteer recruitment centre, at the municipal or community level, may provide a method of matching prospective volunteers with projects they find more relevant and rewarding. Given that many municipalities have volunteer recruitment and referral services organizations in place,,$^{10}$ it is suggested that CED organizations use these organizations as a recruitment vehicle. Such a matching process is expected to increase the level of participation and the level of volunteer satisfaction, thus leading to more volunteer hours and higher volunteer retention rates.

Given that voluntary participation in CED and making charitable donations are complementary and that CED organizations are often involved in attracting both volunteers and donations, the organizations may benefit from crossmarketing. The empirical results imply that those who make charitable donations are more likely to participate in CED. 


\section{Lamb (2011)}

\section{CONCLUSION}

The four models associated with the analysis of the determinants of voluntary participation and time devoted to CED in Canada developed for analysis in this paper proved to be robust and stable; however, the statistical analysis faces some challenges and limitations.

First, the empirical analysis in this paper utilizes existing survey data, which results in three limitations:

1. Voluntary participation in a CED organization does not necessarily indicate that it is taking place in the community where the individual resides. While all participation in CED is beneficial, participation by community residents is vital to ensure that CED initiatives are developed and implemented to meet the needs of the community as expressed by the community.

2. A couple of variables believed to be relevant could not be included due to the constraints of using existing survey data. The first is a variable to measure the probability of success of participation, found in related models (Pattie, Seyd, \& Whiteley, 2003; Bryant \& White, 1982). The second is a variable to measure the role of leadership in motivating participation in CED. The role of leadership in developing CED initiatives and in encouraging participation is frequently discussed in the CED literature (Loxley, 2007; Mclntyre \& Lotz, 2006; Shragge, 2003).

3. It is difficult to find quality proxy variables from existing survey data to measure and distinguish between the consumption benefit and the altruistic benefit. Future research could deal with this issue by developing a survey with questions designed to differentiate the two benefits.

Second, individual decisions to participate in CED are thought to be influenced by the socio-economic environment, particularly the labour market situation, the city size, the homogeneity of the population, the government provision on CED initiatives, and the demand for CED initiatives. The current research does not address this issue. Future research is needed to investigate the relevance of such variables (Dowling \& ChinFang, 2007; Ziemek, 2006; Van Dijk \& Boin, 1993).

The comparison of determinants of CED and general volunteering reveals no substantial differences between the benefits motivating individuals to participate in volunteer activities. On the question of devoting additional time to volunteering, the differences are more evident as both private benefits and public benefits positively influence general volunteering while only the private consumption benefit influences additional time for CED. Most of the variation in empirical results between general volunteering and volunteering for CED can be explained by differences in the socio-economic factors. These differences may be partially explained by the contextual differences in the sample populations of those who volunteer in general as compared to those who volunteer for CED. Given that CED is most often focused on communities characterized by lower income and lower education demographics, it is not surprising that household income has a positive effect on volunteering in general but no significant effect on volunteering for CED. Future comparative research could investigate the determinants of volunteering for CED as compared to volunteering for other non-profit sectors, such as sports and recreation, education, religion, and health. 


\section{Lamb (2011)}

Finally, the economic analysis does confirm many of the determinants of participation identified in the qualitative CED research, such as the positive influence of expected benefits and the negative influence of costs such as hours worked for pay. The analysis also reveals the positive influence of some variables that had not been identified, such as age. These newly identified variables should be incorporated into future qualitative CED research. This economic approach to investigating volunteer participation in CED is intended to inform other CED researchers of an alternative method of understanding volunteer motivations. Further, this approach is intended to inform researchers investigating volunteering by revealing the consequences of an economic approach to analyzing volunteer motivations for specific voluntary subsectors. The result of this economic modelling provides important insights into volunteering that are relevant for policymakers and practitioners alike.

\section{ACKNOWLEDGEMENTS}

The author is grateful to Dr. Ehsan Latif and Dr. Mohammad Mahbobi for their assistance with econometric issues pertaining to this research. All remaining errors and omissions are the responsibility of the author. The author is also grateful for meaningful comments made on a presentation of an earlier version of the paper at the Association of Nonprofit and Social Economy Research Conference in Montréal in June 2010. The author appreciates valuable comments by the two blind reviewers and the English language editor of this journal.

\section{NOTES}

1. Refer to the following sources for examples of provincial government engagement in CED: "Using CED Principles to Build Strong Neighbourhoods," http://www.gov.mb.ca/housing/neighbourhoods/news/pdf/forum2.pdf ; "Team players: Good news from Nova Scotia about the role of government in CED," Perry (2003).

2. Market failure is a situation in which a free market fails to allocate goods and services efficiently.

3. CED initiatives often produce goods and services that are public or quasi-public. A public good is by definition both non-rivalrous and non-excludable. Non-rivalrous means the consumption of the good by one individual will not reduce the supply available to other individuals (e.g., cable television, clean air). Non-excludable means it is impossible to exclude anyone from consuming the good (e.g., national defence, fireworks display). A quasi-public good is public in nature but is not completely non-rivalrous and/or non-excludable.

4. Selectivity bias results in the error terms in the hours of participation equation being correlated with their counterparts in the selection equation, and regression results derived from data for the subpopulation of those participating in volunteer activities to be statistically biased and inconsistent measures. The Heckman sample selection model using the maximum likelihood approach is used to mitigate the bias.

5. The maximum likelihood approach is a method of estimating asymptotically efficient parameters of a statistical model.

6. Volunteer organization categories include education and research, culture and recreation, health, social services, environment, development and housing, law, advocacy and politics, philanthropic intermediaries and voluntarism, international, religion, and business and professional associations, union (12 categories) (International Classification of Nonprofit Organizations (ICNPO)).

7. The Wald test for independent equations reveals that the null hypothesis is not rejected, thus the equations are independent and do not require the Heckman selection model to estimate Models 1 and 2 . The Wald test for exogeneity reveals that neither hours worked nor participation in charitable giving are endogenous variables in Model 1 and is thus estimated with a probit model. The Wald test for exogeneity reports hours worked is not endogenous but participating in charitable giving is endogenous, thus the ivprobit model is used to estimate Model 2.

8. The Wald test for independent equations reveals that the null hypothesis is not rejected, thus the equations are independent and 


\section{Lamb (2011)}

do not require the Heckman selection model to estimate Models 3 and 4. The Wald test for exogeneity reveals that hours worked is an endogenous variable in Models 3 and 4 , thus the ivtobit model is used to estimate both models.

9. The Canadian CED Network (CCED-NET) is a national-level member-led organization: www.ccednet-rcdec.ca .

10. For example, in the City of Kamloops, a non-profit organization called Volunteer Kamloops provides volunteer recruitment and referral services for their members, who could be any group undertaking a volunteer project in the community:

www.volunteerkamloops.org/aboutus.htm.

\section{REFERENCES}

Akinboye, O.A., Ayanwuyi, E., Kuponiyi, F.A., \& Oyetoro, J. (2007). Factors affecting youth participation in community development in Remo North Government area of Ogun State. The Social Sciences, 2(3), 307-311.

Andreoni, James. (1990). Impure altruism and donations to public goods: A theory of warm-glow giving. The Economic Journal, $100,464-477$.

Beard, Victoria. (2007). Household contributions to community development in Indonesia. World Development, 35(4), 607-625.

Bryant, Coralie, \& White, Louise. (1982). Managing development in the Third World. Boulder, CO: Westview Press.

Cappellari, Lorenzo, \& Gilberto Turati. (2004). Volunteer labour supply: The role of workers' motivations. Annals of Public and Cooperative Economics, 75(4), 619-643.

Clary, E., Snyder, M., \& Ridge, R. (1992). Volunteers' motivations: A functional strategy for recruitment, placement, and retention of volunteers. Nonprofit Management \& Leadership, 2(4), 333-350.

Clary, E., Snyder, M., \& Stukas, A.A. (1996). Volunteers' motivations: Findings from a national survey. Nonprofit and Voluntary Sector Quarterly, 25, 485-505.

Conn, Melanie. (2006). Why women? In Eric Shragge \& Mike Toye (Eds.), Community economic development: Building for social change (pp.125-137). Nova Scotia: Cape Breton Press.

Dowling, Malcolm, \& Chin-Fang, Yap. (2007). Modern developments in behavioural economics: Social science perspectives in choice. Hackensack, NJ: World Scientific.

Dupont, D.P. (2004). Do children matter? Ecological Economics, 49, 273-286.

Fontan, Jean-Marc, Hamel, Pierre, Morin, Richard, \& Shragge, Eric. (2006). Urban perspectives on CED practice: The Montreal experience. In Eric Shragge \& Mike Toye (Eds.), Community economic development: Building for social change (pp.109-124). Nova Scotia: Cape Breton Press.

Frey, B.S., \& Goette,L. (1999). Does pay motivate volunteers? Working Paper No.7, Institute of Empirical Research in Economics, University of Zurich.

Freeman, Richard B. (1997). Working for nothing: The supply of volunteer labor. Journal of Labor Economics, 15(1), S140-S165.

Hanley, Jill, \& Serge, Luba. Putting housing on the CED agenda. (2006). In Eric Shragge \& Mike Toye (Eds.), Community economic development: Building for social change (pp.183-205). Nova Scotia: Cape Breton Press.

Hibbert, S., Piacentini, M., \& Al Dajani, Haya. (2003). Understanding volunteer motivation for participation in a community-based food cooperative. International Journal of Nonprofit and Voluntary Sector Marketing, 8(1), 30-42. 


\section{Lamb (2011)}

International Classification of Nonprofit Organizations (ICNPO). URL: http://www.statcan.gc.ca/pub/13-015-x/2005000/4153701eng.htm [September 9, 2009].

Lamb, Laura. (2007). Towards an economic theory of community economic development. In John Loxley (Ed.), Transforming or reforming capitalism: Towards a theory of community economic development (pp. 57-86). Halifax: Fernwood Publishing.

Loxley, John. (1986). The economics of community development, Report prepared for the Native Economic Development Program.

Loxley, John. (2007). The state of community economic development in Winnipeg. In J. Loxley, J. Silver, \& K. Sexsmith (Eds.), Doing community economic development (pp.14-23). Halifax: Fernwood Publishing.

Loxley, John. (2007). Elements of a theory of community economic development. In John Loxley (Ed.), Transforming or reforming capitalism: Towards a theory of community economic development (pp. 7-33). Halifax: Fernwood Publishing.

Markey, Sean, Pierce, J.T., Vodden, K., \& Roseland, M. (2005). Second growth: Community economic development in rural British Columbia. Vancouver: UBC Press.

MacIntyre, Gertrude Anne, \& Lotz, Jim. (2006). State of the art: The third option. In Eric Shragge \& Mike Toye (Eds.), Community economic development: Building for social change (pp. 237-247). Nova Scotia: Cape Breton Press.

Mendell, Marguerite, \& Evoy, Lance. (1993). Democratizing capital: Alternative investment strategies. In Eric Shragge (Ed.), Community economic development: In search of empowerment (pp. 44-59). Montreal: Black Rose Books.

Menchik, Paul L., \& Weisbord, B.A. (1987). Volunteer labor supply. Journal of Public Economics, 32, 159-183.

Pattie, Charles, Seyd, Patrick, \& Whiteley, Paul. (2003). Citizenship and civic engagement: Attitudes and behaviour in Britain. Political Studies, 51, 443-468.

Perry, Stewart. (2003). Team players: Good news from Nova Scotia about the role of government in CED. Making Waves, 14 (2), 30-33.

Perry, Stewart. (2009). Equity capital for CED. Making Waves, 20(1), 21-25.

Peterson, D.K. (2004). Recruitment strategies for encouraging participation in corporate volunteer programs. Journal of Business Ethics, 49(4), 371-386.

Province of British Columbia. (1999). Promoting the volunteer and community services sector in British Columbia (DRAFT STRATEGY). Ministry of Human Resources.

Province of Manitoba. (2002). Using CED principles to build strong neighbourhoods. URL: http://www.gov.mb.ca/housing Ineighbourhoods/news/pdf/forum2.pdf [May 19, 2010].

Shragge, Eric. (2003). Activism and social change: Lessons for community and local organizations. Peterborough, Ontario: Broadview Press Ltd.

Shragge, Eric, \& Toye, Michael. (2006). Introduction: CED and social change. In Eric Shragge \& Mike Toye (Eds.), Community economic development: Building for social change (pp. 237-247). Nova Scotia: Cape Breton Press.

Spyker, C.L., \& Peloza, J. (2009). The potential impact of Canadian federal and/or provincial tax credit incentives for volunteeer participation. Edmonton: Volunteer Alberta.

Statistics Canada. 2004 Canada Survey of Giving, Volunteering and Participating (CSGVP). Public Use Microdata File.

Statistics Canada. (2006). Highlights from the 2004 Canada Survey of Giving, Volunteering, and Participating. Catalogue no. 715452-XIE. 


\section{Lamb (2011)}

Statistics Canada. (2009). The International Classification of Nonprofit Organizations. URL: http://www.statcan.gc.ca/pub/13-015x/2005000/4153701-eng.htm [October 10, 2010].

Torgler, Benno, Garcia-Valiñas, M.A., \& Macintyre, A. (2008). Environmental participation and environmental motivation. Working Paper no. 2008-10, Center for Research in Economics, Management and the Arts (CREMA), Switzerland.

Toye, M., \& Chaland, N. (2006). CED in Canada: Review of definitions and profile of practice. In Eric

Shragge \& Mike Toye (Eds.), Community economic development: Building for social change (pp.21-41). Nova Scotia: Cape Breton Press.

Van Dijk, Jourke, \& Boin, Ronald. (1993). Volunteer labor supply in the Netherlands. De Economist, 13(3), 402-418.

Western Economic Diversification. (2010). Community economic development. URL: www.wd.gc.ca/eng/106.asp [October 10, 2010].

Ziemek, Susanne. (2006). Economic analysis of volunteers' motiviations: A cross-country study. The Journal of Socio-economics, $35,532-555$.

\section{About the author / L'auteur}

Laura Lamb is Assistant Professor in the School of Business and Economics, Thompson Rivers University, Kamloops, BC, Canada. Email: Ilamb@tru.ca 